\title{
Disclosure of Islamic Social Reporting in Sharia Banks: Case of Indonesia and Malaysia
}

\author{
Marita Kusuma Wardani \\ Institut Agama Islam Negeri Surakarta Indonesia \\ maritakusumasolo2015@gmail.com \\ Dea Devita Sari \\ Institut Agama Islam Negeri Surakarta Indonesia \\ ddeavta@gmail.com
}

\begin{abstract}
This study aims to analyze the effect of profitability, leverage, the board of Commissioners and the number of sharia supervisory board of the Islamic Social Reporting (ISR) Islamic banks in Indonesia and Malaysia during the period 2014-2016. The dependent variable in this study is Islamic Social Reporting. While the independent variable is profitability, leverage, the board of Commissioners and the number of sharia supervisory board. The population in this study includes all Islamic banks. Samples were selected using a purposive sampling method and acquired 12 units of Islamic banks in Indonesia and 15 units of Islamic banks in Malaysia. Analysis of the data to test the hypothesis used multiple regression (OLS). The results showed that the profitability of significant positive effect on the disclosure of ISR in Islamic banks in Indonesia, but not with Islamic banks in Malaysia. The study also produced findings that the Board of Commissioners of significant positive effect on the disclosure of ISR in both countries. Furthermore, leverage and the number of sharia supervisory boards do not significantly affect the ISR.
\end{abstract}

Keywords: Profitability, Leverage, The Board of Commissioners, Supervisory Board of Sharia, Islamic Social Reporting, Islamic Banks.

\section{A. INTRODUCTION}

Islamic bank principally instills the ethic and social responsibility in a business model practiced. In Islamic business, everyone is responsible in front of Allah for society (Haniffa, 2002). The practice of Corporate Social Responsibility (CSR) is mainly introduced to provide social responsibility to society (Gray et al, 1996).

Islamic Social Reporting (ISR) disclosure in Islamic perspective has to complete two requirements; those are full disclosure and social accountability (Baydoun and Willet, 2000; Hassan, 2015; Othman and Thani, 2009). The progress of CSR in Islamic economics enhances society of institutions based on sharia. The concept of social accountability related to full objective disclosure principle functions in public interest. In Islamic context, people (society) have rights to know the impact of company's activities on society and consider sharia rules if their goals have been achieved (Baydoun and Willet, 2000). 
CSR in Islamic perspective according to AAOIFI (2010) is all actions conducted by Islamic finance institution to fulfill religious, economic, legal, and ethical interest as intermediary finance institution both individuals and institutions which are in a unit. According to Yusuf and Bahari (2012) there are fundamental differences between the concepts of CSR in conventional and Islamic perspectives. CSR in Islamic concept must be in accordance with the Qur'an and Sunnah.

While CSR in western concept sometimes cannot be separated from the interests of the company, so that, the implementation of CSR is biased. Maali et al (2006) stated that there are several critical things in social reporting based on an Islamic perspective, those are accountability; according to this concept said that everything must be accounted for and get the blessing from Allah; social justice, the justice here means to be fair to anyone and not allowed to exploit and do any harm to others; ownership, Islam recognizes the existence of individual ownership, but keep in mind that ownership is not an absolute possession because everything belongs to Allah.

Associated with the interest to express social responsibility of sharia banks, AAOIFI (Accounting and Auditing Organization for Islamic Financial Institution) decides the items in CSR reporting, known as Islamic social Reporting (ISR) (AAOIFI, 2010). So far the measurement of CSR disclosure in sharia banks still refers to Global Reporting Initiative Index (GRI Index) (Haniffa, 2002). That measurement certainly does not appropriate because the GRI Index has not described Islamic principles yet such as undisclosed cases of freedom from the elements of riba, gharar, and transactions which are forbidden by Islam (Firmansyah, 2014).

In ISR index, it has been disclosed about matters relating to Islamic principles such as zakat, sharia compliance status and transactions fixed from the elements of riba and gharar and social aspects as well such as alms (shadaqah), waqf, qardh el hasan, until the worship disclosure in the company's environment.

Government of countries with Muslim populations, for example, Malaysia, Indonesia, and international regulatory institutions which is Accounting and Auditing Organization for Islamic Financial Institutions (AAOIFI) constantly speaks up and strives for development and adoption of reporting formats like CSR reports to be formulated for Islamic finance institutions (Sharani, 2004 and Yunus, 2004). Therefore, both Indonesia and Malaysia try to homogenize the CSR disclosure format in accordance with Islamic principles through AAOIFI institutions. 
Considering sharia banking industry in the world including in Indonesia and Malaysia is currently growing quite rapidly, supported by the issue of CSR practices and disclosures which are increasingly widespread. Furthermore, it is important to conduct research on the practice of social responsibility disclosure in sharia banks reviewed from a perspective which is proper with Islamic rules, Islamic Social Reporting (Firmansyah, 2013).

Based on the statements above, the research on ISR disclosure in Islamic banks in Indonesia and Malaysia was conducted. The reason why Indonesia and Malaysia are the chosen place is that these two countries continuously strive to adopt the same CSR disclosure format taken from AAOIFI. This research uses ISR index which is an adaptation from Haniffa (2002); Othman and Thani (2009) research with some adjustments. The ISR index in this study consists of six themes including: (1) Finance and investment, (2) Products and services, (3) Labor, (4) Society, (5) Environment, and (6) Corporate governance.

Various researches about social responsibility disclosure based on AAOIFI standards have been conducted, but the results of the research pointed out the different results. From several studies conducted found that there were several factors which affected and did not on social responsibility disclosure based on AAOIFI standards. This study used several variables which can influence the disclosure of Islamic Social Reporting, they were: profitability, leverage, the board of commissioner size, and the number of sharia supervisory boards.

The reason for using these variables is that the board of commissioners and the sharia supervisory board have a crucial function in sharia banking. They have a supervisory function on management. With their own authority, the board of commissioners can insist the management disclose CSR. Whereas DPS has a function to monitor the company's operations running in accordance with sharia principles (Khoirudin, 2013).

The size of the sharia supervisory board is the number of its members in a company. DPS has a role in ISR sharia banking disclosure. This is because DPS has authority to oversee the company's compliance on sharia principles, including supervising the distribution of zakat funds, infaq, alms which can be recognized as a form of ISR of the company (Farook, 2011). 
The use of profitability variables in this study was due to inconsistencies in previous result studies examining the relationship of profitability and Islamic Social Reporting (ISR) disclosure. Firmansyah (2013) determined that profitability did not have an influence on Islamic Social Reporting (ISR) disclosure. While the research conducted by Othman et.al (2009), El-Halaby, (2016), and Widiawati and Raharja (2012) found that profitability had a positive influence on Islamic Social Reporting (ISR) disclosure.

This study also applied leverage variables in ISR disclosure. Belkaoui and Karpik (1989) detected that there was a negative relationship between social disclosure and financial leverage level. It means that the higher the debt/capital ratio, the lower the social disclosure because the higher the leverage level, the more likely the company will violate credit agreement. So companies have to present a higher profit at the present than the future. In order that companies can provide higher profits, they must reduce costs (including costs to disclose social information).

\section{A.1. Sharia Enterprise Theory (SET)}

Sharia enterprise theory is an improvement of three motivation theories of CSR; those are legitimacy theory and stakeholder theory. Legitimacy theory is a theory based on social values or regulations applied in society, while stakeholder theory is a theory that prioritizes the interests of stakeholders. The stakeholders here are referred to human. It is different from the stakeholders in SET which are God, human, and nature (Febriany and Arif, 2014: 292).

Sharia enterprise theory refers to the responsibility towards Allah. Absolutely companies or banks particularly sharia banks have to take responsibilities for their performance. One of them is by conducting disclosures, for example, disclosing social responsibility in the annual report of sharia commercial bank (Marharani and Yulianto, 2016).

Social responsibility disclosure is a way for companies to communicate with the stakeholders that the companies give attention to social and environmental influences caused by companies' operational activities. This disclosure aims to show the activities conducted by companies and its influence on society for the sake of business continuity. Some experts argued that the most appropriate theory to disclose the company's social responsibility that is the sharia bank is Sharia enterprise theory (Mansur, 2012). 
Disclosure of Islamic Social Reporting In Sharia Banks: Case of Indonesia and Malaysia

Basically, Sharia enterprise theory commends its main form of responsibility to Allah and then is elaborated on the form of responsibility to human and the environment (Triyuwono, 2012: 358).

\section{A.2. Islamic Social Reporting (ISR) Disclosure}

The term disclosure in accounting refers to the presentation and disclosure of companies' financial report (Choi and Gerhard, 1997: 279). Social responsibility is an inseparable part of companies' activities especially sharia banks which are operated by the Qur'an's and Sunnah's principles (Firmansyah, 2013: 44). With the increasing of CSR's implementation in Islamic perspective, it triggers the increasing desire to make Islamic Social Reporting (Fitria and Hartanti, 2010: 10).

According to Fitria and Hartanti (2010: 10), there are two things which must be disclosed in an Islamic perspective. It is full disclosure and social accountability. The concept of social accountability is related to the full disclosure principle which is aimed to fulfill the public's need for information. In the Islamic perspective, the public has rights to know various information about organizational activities.

\section{A.3. Effect of Profitability on Islamic Social Reporting Disclosure}

Haniffa (2002) found out a positive relationship between the company's profitability and voluntary disclosure level in Islamic banks as higher profits which motivated management to provide superior information because it would increase investor trust. In the Islamic perspective, a company must provide full disclosure in any situation whether it achieves profit or vice versa.

Profitability is a factor which makes the management free and flexible to express social responsibility to investors (Heinze, 1976 in Hackston and Milne, 1996). So that the higher the level of profitability of the company, the greater the disclosure of information on social responsibility (Firmansyah, 2013). Thus the proposed hypotheses are:

$\mathrm{H} 1_{\mathrm{a}}$ : Profitability affects ISR disclosure in Islamic banking in Indonesia. $\mathrm{H} 1_{\mathrm{b}}$ : Profitability affects ISR disclosure in Islamic banking in Malaysia.

\section{A.4. Effect of Leverage on Islamic Social Reporting Disclosure}

Leverage is the company's ability to fulfill its financial obligations both short and 
long-term. According to Belkaoui and Karpik (1989), the decision to disclose social information will be followed by expenditures for disclosure which can reduce income. This means that leverage provides a bad signal for stakeholders.

The stakeholders of the company will be more trust and choose to invest their funds in companies which have a healthy and good financial condition. Therefore, company's managers have to reduce costs (including in disclosing social and environmental reports). Furthermore, their financial performance becomes good. Anggraini (2006) said that higher leverage has an obligation to carry out broader disclosures than lower leverage. By that, the company will provide more comprehensive information about its social disclosure. Based on that fact, the following hypothesis can be formulated as below:

$\mathrm{H} 2_{\mathrm{a}}$ : Leverage affects the ISR disclosure in Islamic banking in Indonesia.

$\mathrm{H} 2_{\mathrm{b}}$ : Leverage affects the ISR disclosure in Islamic banking in Malaysia.

\section{A.5. Effect of the Size of the Board of Commissioners on Islamic Social Reporting Disclosure}

Relating to the size of the board of commissioners, Coller and Gregory (1999) in Sembiring (2005) stated that "the greater the number of commissioners, the easier to control CEO and the monitoring will be more effective. Associated with the disclosure of social responsibility, the pressure on management will also be greater to expressed" (Firmansyah, 2013).

The results of Sembiring's (2005) research showed that the proportion of the board of commissioners affects the level of CSR disclosure. The greater the size of the board of commissioners, the better supervision will be. With a good supervision, it is expected that Islamic social reporting disclosure will be wider because it can minimize information which may be hidden by management. Therefore, the proposed research hypotheses are as follows:

$\mathrm{H}_{\mathrm{a}}$ : The size of the Board of Commissioners affects the ISR disclosure in sharia banking in Indonesia.

$\mathrm{H} 3_{\mathrm{b}}$ : The size of the Board of Commissioners affects the ISR disclosure in sharia banking in Indonesia. 


\section{A.6. Effect of the Number of Members of Sharia Supervisory Board on Islamic Social Reporting Disclosures}

Karim (1999) explained that sharia supervisory board is a perceived need to oversee innovation in banking towards principles applying in Islam. The increasing number of DPS' members can lead to a higher level of CSR disclosure as a capacity to improve monitoring. The minimum number of DPS members is based on AAOIFI standards and requires at least three members. In the research (El-Halaby, 2016), argued that company governance which is explained by the existence of sharia supervisory board significantly signs its relation to the level of disclosure.

Farook (2011) stated that DPS is expected to more represent Islamic law and Islamic principles than management. The increasing number of DPS members perhaps leads to a higher level of ISR disclosure in increasing monitoring.

According to Percy and Stewart (2010) in Wahyuni and Harto (2012) said that the greater the number of DPS members, the greater the monitoring of Islamic law and principles. With an adequate number of DPS, the implementation and disclosure of ISR become more controlled. Based on this statement, the study composes the following hypothesis:

$\mathrm{H} 4_{\mathrm{a}}$ : The number of Sharia Supervisory Board influences ISR disclosure in Islamic banking in Indonesia.

$\mathrm{H} 4_{\mathrm{b}}$ : The number of Sharia Supervisory Board influences ISR disclosure in Islamic banking in Malaysia.

\section{B. DATA AND METHOD}

\section{B.1. Sample Description}

The population in this study was all Islamic banks in Indonesia and Malaysia. Sharia Commercial Banks in Indonesia were 13 and in Malaysia were 16 in the period 2014-2016. The sample in this study was Islamic banks which published their annual reports in 20142016 based on the criteria. The sampling process can be seen in table 1 as follows:

Table 1. The Sampling Process

\begin{tabular}{|c|c|c|c|}
\hline No. & Sampling Criteria & Indonesia & Malaysia \\
\hline & $\begin{array}{l}\text { Sharia Commercial Banks operating nationally } \\
\text { in Indonesia and Malaysia during observation } \\
\text { period in 2014-2016. }\end{array}$ & 13 & 16 \\
\hline
\end{tabular}


Sharia Commercial Banks which had not

2. published annual reports or annual reports during observation period in 2014-2016.

Sharia Commercial Banks which had not

3. published complete annual reports during observation period in 2014-2016.

Sharia Commercial Banks experiencing capital

4. loss and profit during observation period in 2014-2016.

Number of samples which meet the criteria

Year of observation

Total data used in the research
$-$

12

$12 \quad 15$

$3 \quad 3$

36

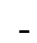

15

3

\section{B.2. Dependent Variable}

The dependent variable in this research was the social reporting disclosure of sharia banks in Indonesia and Malaysia with Islamic Social Reporting (ISR) index. The ISR index in this study was an index of Halabi's (2015) research. The ISR index rating was conducted by scoring from $0-1$, with the arrangement below:

If all the items have been disclosed, the maximum value to obtain is 46 . The calculation of the ISR disclosure index is formulated as follows:

\section{Disclosure Level $=\underline{\text { Total Disclosure Score Fulfilled }} \times 100 \%$

$$
\text { Total Maximum Score }
$$

\section{B.3. Independent Variable}

\section{a. Profitability}

Profitability is a company's ability to obtain benefits or profits. The indicator of profitability in this study used Return on Asset (ROA). (Widiawati and Raharja, 2012):

$$
R O A=\frac{\text { Net Income }}{\text { Total Asset }} \text { 100\% }
$$

\section{b. Leverage}

Leverage is the company's ability to complete all its obligations to other parties. Leverage depicts about how far the assets of company are financed by debt. DER is the dividing result between total debt and total equity (Taufik, Marlina Widianti and Rafiqoh, 2015).

\section{DER $=\underline{\text { Total Debt }}$ \\ Total Equity \\ c. Size of the Board of Commissioners}

What size of the board of commissioners meant here is the number of members of the board of commissioners in a company measured by calculating them who mentioned in the company's annual report (Khoirudin, 2013). 


\section{d. The Number of Sharia Supervisory Board}

The number of sharia supervisory boards is the number of their members in sharia banking which are measured by calculating the members of sharia supervisory board. By AAOIFI assessment standards, the number of sharia supervisory boards in each bank is at least three members. If there are 3 or more than that the score is 1 , if it is less than 3 then it is 0 (Taufik, Marlina Widianti and Rafiqoh, 2015).

\section{B.4. Empirical Model}

To test the hypothesis, this research used multiple regression analysis. The regression model in this study was:

$$
\begin{array}{ll}
\text { ISRD (I) } & =a+b 1 R O A+b 2 D E R+b 3 U D K+b 4 D P S+e \\
\text { ISRD }(M) & =a+b 1 R O A+b 2 D E R+b 3 U D K+b 4 D P S+e
\end{array}
$$

\section{RESULT AND DISCUSSION}

\section{C.1. Descriptive Statistics}

Based on descriptive statistical analysis, it can be shown in Table 2 that the average score of ISR disclosure in sharia banks in Indonesia was $67,61 \%$ with the minimum score which was $56.52 \%$ at Bank Mandiri Syariah and the maximum score which was $78.26 \%$ at Bank Muamalat Indonesia, while the standard deviation was $6.13 \%$. The profitability variable (PROF) has a minimum score $-16.88 \%$ at Maybank Syariah, a maximum score $83.75 \%$ at BNI Syariah, the average score (mean) $-0.014 \%$; and standard deviation 4,321\%. Leverage variable (LEV) has a minimum score $10.53 \%$ at Mega Syariah Bank, a maximum score $374.55 \%$ at BRI Syariah, the average score (mean) $132.03 \%$; and standard deviation 92.18\%. Variable Size of the Board of Commissioners (DK) has a minimum score 3 at Bank Victoria Syariah, a maximum score 6 at Bank Muamalat Indonesia, the average score (mean) 3.50; and standard deviation 0.971. The variable number of sharia supervisory board (DPS) has a minimum score of 2; maximum score 3; the average score (mean) 2.25; and standard deviation of 0.439 .

\section{Tabel 2 . Descriptive Statistic in Indonesia}

\begin{tabular}{lrrrrr}
\hline & N & Minimum & Maximum & \multicolumn{1}{c}{ Mean } & Std. Deviation \\
\hline ISR_I & 36 & .565217 & .782609 & .67608 & .06131 \\
PROF & 36 & -.168857 & .083752 & -.00014573 & .043206978 \\
LEV & 36 & .105307 & 3.745450 & 1.32027742 & .921772250 \\
DK & 36 & 3 & 6 & 3.50 & .971 \\
\hline
\end{tabular}


Journal of Finance and Islamic Banking | Vol. 1 No. 2, July-December 2018

\begin{tabular}{llllll}
\hline DPS & 36 & 2 & 3 & 2.25 & .439 \\
$\begin{array}{l}\text { Valid N } \\
\text { (listwise) }\end{array}$ & 36 & & & & \\
\hline
\end{tabular}

Whereas in table 3 it can be shown the results of descriptive statistics on sharia banks in Malaysia that the ISR disclosure variable has a minimum score $73.91 \%$ at Affin Islamic Bank Berhad bank and a maximum score $80.43 \%$ at Asian Finance Bank Berhad, the average score (mean) $75.99 \%$ and standard deviation $17.92 \%$. The profitability variable (PROF) has a minimum score 0.49\% at the Public Islamic Bank Berhad and a maximum score $16.74 \%$ at Affin Islamic Bank Berhad, the average score 2.51\%; and standard deviation of $22.79 \%$. Leverage variable (LEV) has a minimum score $393.92 \%$ at an Asian Finance Bank Berhad and a maximum score 4070.47\% at Alliance Islamic Bank Berhad, the average score (mean) $1213.05 \%$, and standard deviation $543.45 \%$. Variable Size of the Board of Commissioners (DK) has a minimum score of 3 and a maximum score 7 with the average score (mean) 5.31 and standard deviation of 0.973 . The variable number of sharia supervisory board (DPS) has a minimum score of 4 and a maximum score of 9 while the average score (mean) was 5.78, and standard deviation of 1.126 .

Tabel 3 . Descriptive Statistic in Malaysia

\begin{tabular}{lrrrrr}
\hline & N & Minimum & Maximum & \multicolumn{1}{c}{ Mean } & Std. Deviation \\
\hline ISR_M & 45 & .739130 & .804348 & .75990338 & .017923883 \\
PROF & 45 & .004955 & .167423 & .02510878 & .022795806 \\
LEV & 45 & 3.939191 & 40.704721 & 12.130484 & 5.434551224 \\
DK & 45 & 3 & 7 & 5.31 & .973 \\
DPS & 45 & 4 & 9 & 5.78 & 1.126 \\
Valid N & 45 & & & & \\
(listwise) & & & & & \\
\hline
\end{tabular}

The results of descriptive statistics in tables 2 and 3 turned up that Islamic Social Reporting disclosure in Malaysia was higher than in Indonesia because the ISR score in Malaysian Islamic banks was $75.99 \%$ while in Indonesian Islamic banks was $67.61 \%$. The value of profitability in Malaysia was higher than in Indonesia because the profitability score in Malaysian Islamic banks was $2.51 \%$ and in Indonesian Islamic banks was $0.014 \%$. The leverage score in Malaysia was higher than in Indonesia indicated by the leverage score in Malaysian Islamic banks that was $1213.05 \%$ and in Indonesian Islamic banks that was $132.03 \%$. The number of Board of Commissioners in Malaysia was greater than in Indonesia because their number in Malaysian Islamic banks was 7 while their number in Indonesian Islamic banks was 6. So did the number of sharia supervisory boards 
in Malaysia which was greater than in Indonesia that was 9 and in Indonesian Islamic banks that were 3 .

\section{C.2. Regression Result}

In using multiple regression methods, it is necessary to test the feasibility of the data used in the study before, which is using the classical assumption test. The results of data testing on various classical assumption tests can be explained that based on the normality test on research data in Indonesia and in Malaysia with the Kolmogorov-Smirnov test (KS) resulted in an Asymp score. Sig (2-tailed) was 0.391> (0.05) and 0.200> (0.05). So, it can be concluded that all the research data distributed normally.

In multicollinearity test, it is shown by tolerance and VIF score as in table 4. The result of tolerance score was $>0.10$ and VIF result score was $<10$. It means that there is no multicollinearity between research variables.

Tabel 4. Multicollinearity Test

\begin{tabular}{ccccc}
\hline \multirow{2}{*}{$\begin{array}{c}\text { research } \\
\text { variables }\end{array}$} & \multicolumn{2}{c}{ Indonesia } & \multicolumn{2}{c}{ Malaysia } \\
\cline { 2 - 5 } & Tolerance & VIF & Toleranc & VIF \\
e & \\
\hline PROF & .974 & 1.026 & .995 & 1.005 \\
LEV & .489 & 2.043 & .871 & 1.148 \\
DK & .576 & 1.735 & .963 & 1.039 \\
DPS & .618 & 1.617 & .872 & 1.147 \\
\hline
\end{tabular}

While heteroscedasticity test using glejser test analysis is shown in table 5, the result was a significant probability above trust level of 5\%. Hence, the regression model does not contain heteroscedasticity.

Tabel 5. Heteroscedasticity Test

\begin{tabular}{crr}
\hline research & \multicolumn{2}{c}{ significant probability } \\
\cline { 2 - 3 } variables & Indonesia & Malaysia \\
\hline PROF & .684 & .944 \\
LEV & .841 & .832 \\
DK & .438 & .804 \\
DPS & .127 & .787 \\
\hline
\end{tabular}

In answering the research hypothesis, it was used regression analysis whose result was shown in table 5, the following: 
Tabel 6. Regression Result

\begin{tabular}{|c|c|c|c|}
\hline \multirow{3}{*}{ Variable } & \multirow{3}{*}{$\begin{array}{l}\text { Predicted } \\
\text { Sign }\end{array}$} & \multicolumn{2}{|c|}{ ISR } \\
\hline & & \multicolumn{2}{|c|}{ Regression Coefficient } \\
\hline & & Indonesia & Malaysia \\
\hline Constant & & 0.549 & 0.734 \\
\hline PROF & + & $0.302 *$ & 0.098 \\
\hline LEV & + & 0.007 & -0.001 \\
\hline DK & + & $0.038 * * *$ & $0.008 * * *$ \\
\hline DPS & + & -0.008 & -0.002 \\
\hline Adj. $\quad \mathrm{R}^{2}$ & & 49.1 & 15.8 \\
\hline$(\%)$ & & 0.000 & 0.027 \\
\hline Sig F & & 36 & 45 \\
\hline $\mathrm{N}$ & & & \\
\hline
\end{tabular}

Based on regression analysis, it can be envisaged that testing in Indonesia produces a profitability variable affecting significantly and positively on the level of $10 \%$ of the ISR variable. Likewise, the board of commissioners' variable affects significantly positively on the level of $1 \%$ of ISR. These results supported the research hypothesis. On contrary with leverage variables and sharia supervisory boards, this study found results that did not have a significant effect on ISR.

In a testing in Malaysia, it can be concluded that only the board of commissioners' variable affects significantly and positively on ISR at the level of $1 \%$. While the profitability, leverage, and sharia supervisory variables have no significant effect on the ISR.

\section{C.3. Discussion}

Regression results pointed out that profitability has a positive effect on ISR disclosure on sharia banks in Indonesia. This means that the higher the level of profitability of the company, the greater the disclosure of information about social responsibility. These results support research hypotheses and Haniffa's research (2002) who found a positive relationship between corporate profitability and the level of voluntary disclosure in Islamic banks as higher profits motivating management to provide superior information because it will increase investor trust.

This study also generated a significant positive influence between the variables of the board of commissioners and ISR disclosures on sharia banks in Indonesia and Malaysia. This means that the greater the size of the board of commissioners, the better supervision will be. Anggraini (2015) explained that with a good supervision, it is expected that ISR 
disclosure will be wider because it can minimize information that might be hidden by management. These results support the hypothesis and the results of previous studies conducted by Khoirudin (2013) pointing out that the size of the board of commissioners affects ISR disclosure.

However, in this study, there was no significant effect on profitability variables with ISR disclosures on sharia banks in Malaysia. It indicates that sharia bank in Malaysia does not conduct ISR disclosure depending on profitability conditions of sharia banks. Hanifa's research (2002) stated that in Islam perspective, companies which have an intention to make disclosures will not consider whether the benefits or loses. However, sharia banks still disclose the information on Islamic Social Reporting regardless of the high or low profit gained. It is because the company regards Islamic Social Reporting disclosure as a necessity. The company realizes that Islamic Social Reporting disclosure is very important as a form of the company's transparency in order to increase the trust and rate in the report user's view (Ramadhani, 2016). The result of this study was consistent with the research result conducted by Ramadhani (2016) showing that profitability was not affected by the disclosure of Islamic Social Reporting.

This study also resulted in findings that leverage variables in Islamic banks both in Indonesia and Malaysia have no significant effect on ISR disclosure. It supports Taufik, Marlina Widianti and Rafiqoh (2015) statement that it is caused by the ability of creditors to get information and other disclosures apart from the annual report. Therefore, creditors can obtain information and other disclosures through direct interviews at the company or ask management about financial information and discussion about significant financial information. Henceforth, creditors do not demand a complete ISR disclosure of the company. So if the leverage is high or low, it will not affect ISR disclosure.

The variables of the sharia supervisory board measured by the number of sharia supervisory boards in this study have no significant effect on ISR disclosure in Indonesian and Malaysian sharia banks as well. This is possible because the existence of DPS in sharia banks merely to enforce regulations that require that Islamic banks must have a sharia supervisory board (SSB) and SSB is more focused on their duties and responsibilities in operational activities of sharia banking. The results of this study were in accordance with the results of previous studies conducted by Khoirudin (2013) and Wahyuni and Harto (2012). 


\section{CONCLUSION}

This study examined the variable effect of profitability, leverage, the board of commissioners and the sharia supervisory board on the disclosure of Islamic social reporting on sharia banks in Indonesia and Malaysia. The results showed that profitability had a positive significant effect on ISR disclosure on sharia banks in Indonesia neither in Malaysia. The study also found that there was a positive significant effect between the board of commissioners' variables and ISR disclosure both in Indonesian and Malaysian sharia banks. However, the result of leverage and sharia supervisory board variable did not significantly affect ISR disclosure on Islamic banks both in Indonesia and Malaysia. Based on the results of the study, it can be concluded that although these two countries are allied and have some similarities in populations which are Muslim and the rapid growth of sharia banking, however, the ISR disclosure of sharia banks in Indonesia and Malaysia can be different. It is shown by the relationship between the variable of profitability and ISR disclosure resulting different results in Indonesia and Malaysia.

\section{Reference}

AAOIFI. 2010. Accounting an Auditing Organization for Islamic Financial Institutions (AAOIFI). Accounting Auditing and Governance Standards for Islamic Institutions. www.aaoifi.com.

Anggraini, R. 2006. Pengungkapan Informasi Sosial dalam Laporan Keuangan Tahunan (Studi Empiris pada Perusahaan-Perusahaan yang Terdaftar Bursa Efek Jakarta). Simposium Nasional Akuntansi IX, Padang.

Baydoun, N and Willet, R. 2000. Islamic Corporate Report, ABACUS, 36 (1), pp.71-90.

Belkaoui, Ahmad \& Karpik, Philip G. 1989. "Determinants of the Corporate Decision to Disclose Social Information”. Accounting Auditing \& Accountability Journal, Vol. 2 Issue: 1

Choi, Frederick D.S dan Gerhard G. Mueller. 1997. Akuntansi Internasioanl. $1^{\text {st }}$ Edition. Jakarta: Salemba Empat.

El-Halaby, Sheriff and Khaled Hussainey. 2015. The Determinants of Social Accountability Disclosure: Evidence from Islamic Bank Around the World. International Journal Business, 20 (3), ISSN 1083-4346.

El-Halaby, Sherif. 2016. Determinant of Compliance with AAOIFI Standards by Islamic Banks. International Journal of Islamic and Middle Eastern Finance and Management, Vol.9, Iss 1 pp. 
Farook, Sayd. 2011. Determinants of Corporate Social Responsibility Disclosure: the Case of Islamic Bank. Journal of Islamic Accounting and Business Research, Vol.2 no.2.

Febriani, Rizky Nia dan Arif Lukman Santoso. 2014. Corporate Governance dan Kualitas Laba Bank Umum Syariah di Indonesia Tahun 2007-2012. Paper was presented in Koferensi Ilmiah Akuntansi 2. Universitas Pembangunan Nasional Veteran Jakarta.

Firmansyah, I. 2013. Tanggung Jawab Sosial Perbankan Syariah: Suatu Kajian dalam Pengungkapan Laporan Tahunan Menurut Pandangan Islam (Studi di Indonesia dan Malaysia). Bandung: Mujahid Press.

Firmansyah, I. 2014. ISR sebagai Proksi Pengungkapan CSR Bank Muamalat Indonesia dan Bank Syariah Mandiri. Jurnal Ilmiah ESAI, Vol.8, No. 1, 1-11.

Fitria, S., Hartanti, D. 2010. Islam dan Tanggung Jawab Sosial: Studi Perbandingan Pengungkapan Berdasarkan Global Reporting Initiative Indeks dan Islamic Social Reporting Indeks. Simposium Nasional Akuntasi XII, Purwokerto.

Gray. R.H., Owen, D. dan Adam, C. 1996. Accounting dan Accountability: Changes and Challenges in Incorporate Social and Environmental Reporting. London: Prentice Hall.

Haniffa, R. 2002. Social Reporting Disclosure: an Islamic Perspective. Indonesian Management and Accounting Research. I.128-146.

Hackston, David dan Markus J Milne. 1996. Some Determinant of social and environmental disclosures in new zealand companies. Accounting Auditing and Accpuntability Journal, Vol. 9, No. 1, pp 77-108.

Hassan, Abul and Sofyan Syafri Harahap. 2015. Exploring Corporate Social Responsibility Disclosure: The Case of Islamic Bank. International journal of Islamic and middle eastern finance management, vol. 3, Iss 3pp.203-227.

Heinze, D. C. 1976. Financial Correlates of a Social Invoivement Measure. Akron Business and Economic Review, 7(1), pp 48-51.

Karim, R. A. A. 1999. Accounting in Islamic Financial Institutions. Accounting and Business Magazines. July/Agustus 1999.

Khoirudin. 2013. Corporate Governance dan Pengungkapan Islamic Social Reporting pada Perbankan Syariah di Indonesia. Accounting Analysis Journal.vol 2, no 2, ISSN 2252-6765

Maali, B., Casson,P., dan Napier, C. 2006. Social Reporting by Islamic Bank. ABACUS, vol.42,No.2, 266-289. 
Marharani, Amanda Kyka dan Yulianto, Agung. 2016. Faktor-Faktor yang Mempengaruhi Tingkat Islamic Social Reporting pada Bank Syariah. Accounting Analysis Journal jilid 5 terbit 1.

Mansur, S. 2012. Pelaporan Corporate Social Responsibility Perbankan Syariah dalam Perspektif Shariah Enterprise Theory (Studi Kasus pada Laporan Tahunan PT. Bank Syariah Mandiri). Jurnal Ekonomi dan Hukum Islam, Vol.2, No.2, 107-133.

Othman, R., A. Md. Thani, E.K. Ghani. 2009. Determinants of Islamic Social Reporting Among Top Shariah-Approved Companies in Bursa Malaysia. Research Journal of International Studies, Vol. 12.

Ramadhani, Ieman Aji. 2016. Pengaruh Pengungkapan Sustainability Report terhadap Nilai Perusahaan dengan Profitabilitas sebagai Moderasi (Studi Kasus pada Perusahaan High-Profile Go Public yang Mempublikasikan Sustainability Report pada Tahun 2009-2012). Journal Economic Brawijaya, vol. 4, no. 2.

Sharani, U.M. 2004. "Corporate Social Responsibility Underlines Values Propagated by Islam”. Bernama. Kuala Lumpur, June 21, p. 1.

Sembiring, E. R. 2005. Karakteristik Perusahaan dan Pengungkapan Tanggung Jawab Sosial: Studi Empiris pada Perusahaan yang Tercatat di Bursa Efek Jakarta. Simposium Nasional Akuntansi VIII, Solo, September 15-16.

Taufik, Widianti, Marlina dan Rofiqoh. 2015. Pengaruh Islamic Social Governance Score, Leverage, dan Profitabilitas terhadap Islamic Social Reporting Index pada Bank Umum Syariah di Indonesia. Jurnal Manajemen dan Bisnis Sriwijaya, Juni, vol. 13 No. 2.

Triyuwono, I. 2012. Perspektif, Metodologi dan Teori Akuntansi Syariah. Jakarta: Rajawali Pers.

Wahyuni, Tri dan Puji Harto. 2012. Analisis Pengaruh Corporate Governance dan Karakteristik Perusahaan terhadap Keberadaan Komite Manajemen Risiko (Studi Kasus pada Perusahaan yang Listing di BEI periode 2008-2010. Diponegoro Journal Of Accounting. Volume 1, nomor 2, tahun 2012, halaman 1-12.

Widiawati, Septi dan Surya Raharja. 2012. Analisis Faktor-Faktor yang Mempengaruhi Islamic Social Reporting Perusahaan-Perusahaan yang Terdapat pada Daftar Efek Syariah Tahun 2009-2011. Diponegoro Journal of Accounting. Volume 1, nomor 2, tahun 2012, halaman 1-15.

Yunus, k. 2004. “Investment in Islamic Fund soars”. Business Times. Kuala Lumpur, June 23, p. 2.

Yusuf, M.Y dan Z, Bahari. 2012. Corporate Social Responsibility in Islamic Banking Forward Poversty alleviation. Paper was presented in $8^{\text {th }}$ International Conference on Islamic Economics and Finance. 